\begin{tabular}{|c|c|c|}
\hline EREM 75/2 & \multicolumn{2}{|c|}{$\begin{array}{c}\text { Hedonic Analysis of Housing Prices and Development in } \\
\text { Kaunas: Heritage Aspect }\end{array}$} \\
\hline $\begin{array}{l}\text { Engineering and Management } \\
\text { Vol. } 75 \text { / No. } 2 \text { / } 2019\end{array}$ & Received 2019/02 & Accepted after revision 2019/04 \\
\hline DOI 10.5755/j01.erem.75.2.22823 & \multicolumn{2}{|c|}{ crossef http://dx.doi.org/10.5755/j01.erem.75.2.22823 } \\
\hline
\end{tabular}

\title{
Hedonic Analysis of Housing Prices and Development in Kaunas: Heritage Aspect
}

\section{Kastytis Rudokas}

Institute of Architecture and Construction, Kaunas University of Technology, Kaunas, Lithuania

\section{Mantas Landauskas}

Faculty of Mathematics and Natural Sciences, Kaunas University of Technology, Kaunas, Lithuania

\section{Odeta Viliūnienè, Indrẻ Gražulevičiūtė-Vileniškè*}

Faculty of Civil Engineering and Architecture, Kaunas University of Technology, Kaunas, Lithuania

*Corresponding author: indre.grazuleviciute@ktu.lt

Urban economists have stressed the importance of various amenities for the attractiveness of urban areas for residents and businesses, and built cultural heritage may be considered as one of such amenities, the benefits of which should not be overlooked. This research was aimed to analyse the influence of the heritage aspect including the heritage status or features of the building and the historic built environment in general on real estate prices and development in Kaunas using the hedonic price method. Two sets of data were collected for the analysis, i.e., general, including heritage buildings and including new construction since 2013. The research demonstrated that the heritage status and the year of construction (as older buildings can be considered having heritage features) have no significant positive influence on real estate prices. Meanwhile, location, heritage context and architectural distinctiveness of new architecture have a direct influence on real estate prices. The heritage context correlates with architectural quality of new construction as well. This reveals the benefits of heritage context both for real estate developers and households; however, the study shows the unemployed social-economic potential of historic buildings as generators and maintainers of the heritage context.

Keywords: hedonic price method, built heritage, real estate, heritage context, socio-economic significance of heritage, Kaunas. 


\section{Introduction}

In the last decades of the $20^{\text {th }}$ century, numerous economic valuation techniques were adapted and applied for valuation of built heritage as both market and non-market good; they are usually subdivided into stated and revealed preference techniques (Mason, 2005; Navrud \& Ready, 2002; Throsby, 2002). Some of these techniques are shared between the fields of heritage studies, real estate assessment, evaluation of artworks, ecosystem assessment, etc., and the hedonic price method is such an example. The hedonic price method is based on the existing market data and is, thus, considered a revealed preference technique. In the field of housing price evaluation, the hedonic price method is attributed to the category of advanced methods together with artificial neural networks, casebased reasoning and spatial analysis (Xiao, 2017).

The theoretical fundamentals of the hedonic price method were developed in the 70s and 80 s by Lancaster and Rossen (Lazzaro, 2006). Lancaster recognised composite or differentiated goods, the utilities of which are not based on the goods themselves but instead on the individual characteristics of goods or their composite attributes, and thus "the consumers make their purchasing decision based on the number of good's characteristics as well as per unit cost of each characteristic" (Xiao, 2017). The basic idea of Rosen's hedonic function is to estimate the demand for characteristics of these composite goods and, for example, in the case of real estate valuation, to be able to show that property prices are determined by a large number of different factors (Nilsson, 2011); meanwhile, the hedonic modeling can be used to predict future transaction prices (Monson, 2009). According to Fan (2006), Burinskiene and Rudzkiene (2006), Ruijgrok (2006), Gabrielli and Farinelli (2017) and many others, the market price of a building may be influenced by its characteristics, such as internal and external area, maintenance conditions, design features, and even the author of the project, location characteristics, such as the prestige of the district, distance to public spaces, infrastructure development, noise, pollution levels, etc.

The literature review demonstrated the application of the hedonic price method in different real estate analyses and the interest in this method is growing due to the increasing availability of large databases of real estate transactions and listed prices (Lazrak et al., 2014). For example, Anderson and West (2006), Jim and Chen (2006), Ryan and Weber (2007), Jayantha and Lau (2016) and many others have used the hedonic method to determine the impact of characteristics of residential properties and their environmental on their market prices. Ryan and Weber (2007) analysed the influence of design quality on real estate prices. Girard et al. (2012) distinguish the entire group of such hedonic price studies that evaluate architecture and architectural quality, such as style, number of façade elements or general quality of new and historic buildings. Such assessments may include not only physical but also social environmental characteristics. For example, Tita et al. (2006) used the hedonic price method to analyse the impact of the level of crime in the area on housing prices. The hedonic pricing method is increasingly integrated with urban spatial analysis, and such studies are referred to as the spatial hedonic pricing (Lazrak et al., 2014; Wen et al., 2017); for example, Wen et al. (2017) analysed spatial heterogeneity in housing prices.

Literature demonstrates that the hedonic price method can be applied to other types of market and non-market goods as well. Since the 80 s of the $20^{\text {th }}$ century, it has been used for the assessment of artworks and movable cultural goods (Lazzaro, 2006). The method is used in the context of tourism and its influencing factors (Saló et al., 2014; Bilbao-Terol et al., 2017). Donnelly (1991), Steiner et al. (2004) and many others have analysed the possibilities to apply the hedonic price method to environmental goods. Cultural heritage, especially the built heritage that is closely related with real estate market, is not an exception in this context. Throsby (2001), Mourato and Mazzanti (2002), Mason (2002, 2005), Ruijgrok (2006), Girard et al. (2012) and Lazrak et al. (2009, 2014) have analysed the potential of the hedonic pricing method in this context. An overview of hedonic price studies with regard to cultural heritage by Lazrak et al. (2009) allowed identifying 16 noteworthy studies, the earliest dating 1983 and the majority carried out 
in the United States. In the recent years, the number of such hedonic analyses of heritage has increased in the Western European context as well (see Moro et al, 2013, Gabrielli and Farinelli, 2017; Franco and Macdonald, 2018). Hedonic price studies with the heritage aspect can be subdivided into several categories (Girard et al., 2012; Lazrak et al., 2009, 2014). One of these is the assessment of the effects of heritage objects' listing (designation) or the impact of cultural heritage characteristics. For example, market price differences between buildings listed as heritage and non-listed regular buildings can be analysed (Girard et al., 2012). Ruijgrok (2006) attempted to monetise what she identified as the "housing comfort value" of the heritage buildings in the Netherlands and found a positive effect of almost 15\%. Lazrak et al. (2014) analysed the Dutch urban area of Zaanstad and concluded that "to purchase a listed building, buyers are willing to pay an additional $26.9 \%$, while surrounding houses are worth an extra $0.28 \%$ for each additional listed building within a $50 \mathrm{~m}$ radius. Houses sold within a conservation area appear to gain a premium of $26.4 \%$ which confirms the existence of a 'historic ensemble' effect". This study shows that the influence of district designation or the historic character of the area on the property values can be analysed as well (Girard et al., 2012; Oba \& Noonan, 2017). A study in Germany, Berlin, (Ahlfeldt \& Maennig, 2012) demonstrated that landmarks were found to have positive external effects on surrounding property prices within a distance of approximately $600 \mathrm{~m}$. In a study in Sweden (Nilsson, 2011), the hedonic price method was applied to analyse the relation between cultural landscape characteristics and property values. It showed that "the percentage of land within communities devoted to local and national preservation areas leads to a considerable increase in house prices (up to 12\%) comparing to communities that have less land devoted to preservation areas." The continuous improvements of the methodology including the integration of the spatial dimension (Lazrak et al., 2014), adjusting the technique to a special group of heritage buildings (Gabrielli \& Farinelli, 2017) and development of new hedonic models and their application to influence policy deign (Oba \& Noonan, 2017) should be mentioned as well.

The reviewed literature as well as the earlier reviews (Girard et al., 2012; Lazrak et al., 2009, 2014) demonstrate that the applications of the hedonic price method are relatively rare in heritage studies and, in cases when necessary market data are available, encourage to intensify research in this field. The hedonic price method is the most suitable for capturing the influence of the built heritage and historic environment on the attractiveness of a specific place for households and businesses, which is the object of this research. The above identified reasons justify the application of the hedonic price method in this study.

The aim of the research was to analyse the influence of the heritage aspect on real estate development and prices in Kaunas.

The hypothesis of the research consists of the following statements:

Heritage status of the building (the building is listed or built before 1950) influences its price in the real estate market;

Heritage context (territory that is considered a historic center or district or the zone of its visual, cultural, economic, etc. influence) can have an impact on the real estate prices of non-heritage buildings (built during the Soviet period, post-Soviet era and recent developments starting from 2013).

Heritage context can have an impact on the quality of new architecture: the new real estate developments in the territory that is considered the historic centre or district or the zone of its visual, cultural, economic, etc. influence are of higher architectural quality (have a distinctive aesthetic character).

To test the hypothesis, two sets of data (general, including heritage buildings and including new construction since 2013) on the real estate (residential flats and houses) characteristics and prices in Kaunas were prepared; the hedonic analysis method, correlation analysis, and other methods were applied.

\section{Method and Data}

Research data. The data for the research were gathered from a number of online websites containing advertisements on real estate for sale. The timeframe for data collection was May and June of 2018. Two separate sets of data were formulated in order to 
check the hypothesis of the research and to identify the possible influence of the heritage aspect on the real estate development and prices in Kaunas. Two datasets were needed in order to understand how the heritage context influences recent intensified real estate development in Kaunas. The first set included data on real estate with different characteristics including historic buildings, buildings of the Soviet and post-Soviet periods located in different areas of Kaunas. There were 226 observations in total of 18 variables. The variables are listed and described in Table 1. Despite the rather small dataset, it took significant time to compile it, as the expert attention was required to evaluate the physical status of the building, to check if the object is included in the Register of Cultural Heritage Properties etc.

\section{Table 1}

Summary of the variables in the first dataset

\begin{tabular}{l|l}
\hline \multicolumn{1}{c|}{ Variable name } & \multicolumn{1}{c}{1} \\
\hline District & \multicolumn{1}{c}{ Type } \\
\hline Street & Text (factor) \\
\hline IsHeritageTerritory & Text (factor) \\
\hline IsHeritageObject & Integer (0 or 1) \\
\hline Floors & Integer (0 or 1) \\
\hline Floor & Integer \\
\hline Area & Integer \\
\hline Rooms & Numeric \\
\hline Year & Integer \\
\hline ConstructionMaterials & Integer \\
\hline HeatingSystem & Text (factor) \\
\hline Completeness & Text (factor) \\
\hline NeedsRepairs & Text (ordered factor, 1 or 2) \\
\hline PhysicalStatusOfHouse & Integer (0 or 1) \\
\hline Parking & Text (ordered factor, 1 to 4) \\
\hline Balcony & Integer (0 or 1) \\
\hline Price & Integer (0 or 1) \\
\hline PriceSqM & Numeric \\
\hline & Numeric \\
\hline
\end{tabular}

The second set of the data included the real estate objects for sale built in 2013 or later in different locations of Kaunas. There were 146 observations in total of 14 variables. The variables are listed and described in Table 2.

\section{Table 2}

Summary of the variables in the second dataset

\begin{tabular}{l|l}
\hline \multicolumn{1}{c|}{ Variable name } & \multicolumn{1}{c}{1} \\
\hline District & \multicolumn{1}{c}{ Type } \\
\hline Street & Text (factor) \\
\hline Project & Text (factor) \\
\hline UniqueArchitecture & Text (factor) \\
\hline IsHeritageTerritory & Integer $(0$ or 1$)$ \\
\hline Year & Numeric $(0,0.5$ or 1$)$ \\
\hline Floors & Integer \\
\hline Floor & Integer \\
\hline Rooms & Integer \\
\hline Area & Integer \\
\hline Completeness & Numeric \\
\hline Parking & Text (ordered factor, 1 or 2$)$ \\
\hline Price & Numeric $(0,0.5$ or 1$)$ \\
\hline PriceSqM & Numeric \\
\hline Heritage & Numeric \\
\hline & Numeric $(0,0.25,0.5,0.75$ or 1$)$ \\
\hline & \\
\hline
\end{tabular}

Variable District identifies the district of Kaunas city where the property is located; variable Street identifies the name of the street of the property; variable IsHeritageTerritory defines whether the property is located in the protected territory; IsHeritageObject identifies whether the property is listed as a heritage object; Floors identifies the number of floors in the building where the property is located; Floor identifies the floor in which the property is located; Area identifies the total area of the property in square meters; Rooms identifies the number of rooms in the property; Year identifies the year of construction of the buildings; ConstructionMaterials identifies the type of materials of the building; HeatingSystem identifies the type of the heating system; Completeness identifies whether the property is completely installed or is just partially installed as it is characteristic for the flats of new construction for sale; NeedsRepairs demonstrates whether the interior of the property needs repair or not, as the need for repair is characteristic for the properties of the Soviet and earlier 
periods; PhysicalStatusOfHouse identifies the physical state of the exterior of the building where the property is located: good (4), satisfactory (3), average (2), bad (1); Parking defines whether there is a possibility to park a car for the user of the property; Balcony defines whether the property has a balcony; Price is for the total price of the property in Euros; and PriceSqM identifies the price for the square meter of the property. In the second set of the data, Project identifies the name of the real estate development project as such projects are usually assigned names for identity and marketing purposes. IsHeritageTerritory here also defines the zone of influence of heritage territory where 1 means that the building is located in the officially protected heritage territory, 0.5 means that the building is located in the zone of active influence of the historic environment and linked with it by direct visual, compositional or territorial links, and 0 refers to buildings located in the territory not directly influenced by the historic environment. The new variable Heritage subjectively summarising IsHerritageTerritory, District and Street of the second data set was introduced in order to reflect the heritage character of specific districts of Kaunas, as some of them are considered historic with a certain aura of prestige determined by the heritage aspect, which might influence real estate prices. The heritage significance coefficient ranging from 0 to 1 was assigned to Kaunas historic districts based on the expert valuation. Centras and Senamiestis were attributed coefficient 1 , because their territories are officially listed and protected as heritage. Žaliakalnis was attributed 0.75, Freda - 0.5, Aleksotas - 0.25, Vilijampole -0.25 , Žemieji Šančiai -0.25 , and the remaining districts -0 . This coefficient identifies the intensity of urban heritage mass existing in the district. The variable UniqueArchitecture is for the architectural quality of the new construction property, the architectural quality of the exterior of the building is considered in this variable. Thus, the character of the new architecture has been evaluated as well. Expert approach was not precisely targeted at the artistic quality of architecture, but was used to evaluate whether the project is of indifferent expression, i.e., close to standard uniform housing projects (evaluated as 0 ) or the design aims at uniqueness and uses at least some architectural artistic means (evaluated as
1). For both sets of the data, the price will be treated as a dependent variable and all the rest will be considered as predictors or independent variables in the next sections.

Hedonic regression models. From the mathematical point of view, hedonic price is defined as linear regression. Often some variables are transformed by a natural logarithm in order to make the data meet formal requirements of regression. In general, the equation for hedonic price is defined as follows:

$\ln ($ Price $)=\ln \left(\right.$ Factor $\left._{1}\right)+\ln \left(\right.$ Factor $\left._{2}\right)+$ factor $_{3}+\ldots+$ + factor $_{n}+$ Intercept $+\varepsilon$.

General set of data. The correlation matrix of factor pairs is presented in Fig. 1. It must be noted that correlations with some factors (ConstructionMaterials, HeatingSystem, District and Street) are not mathematically meaningful as they are not ranked in value. We will transform these variables to separate binary factors for hedonic price. Fig. 1 shows that the strongest linear relationship exists between Area and Rooms (0.84). This suggests that only one of these variables could be considered in the final model. One can remember this fact if Area and Rooms are present in the hedonic regression model. The strongest negative

\section{Fig. 1}

Correlation matrix (Spearman rank correlation) for factor pairs in the general set of data. The white cells depict statistically insignificant correlations $(p=0.01)$.

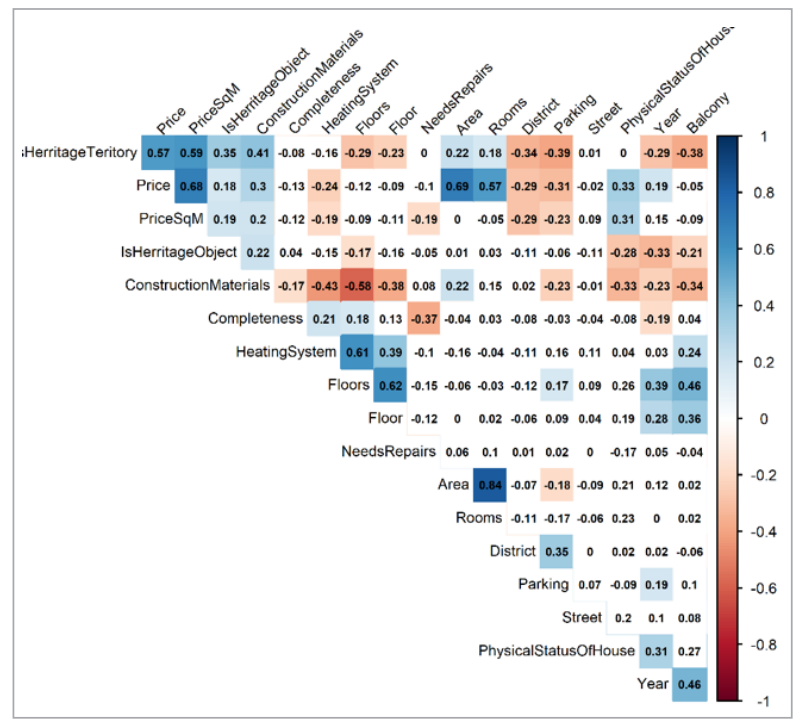


linear relation exists between ConstructionMaterials and Floors, Aathough it is only -0.58 and, in this case, is not treated as multicollinearity. It can also be noted that Price correlates more strongly with almost each factor compared with PriceSqM. This enables us to pick Price for hedonic regression and leave PriceSqM out.

At first, we enter all the factors to hedonic regression to get a broader picture of possible interconnection between the factors and the price. All the values for ranked factors are treated as integers 1,2 and so on. Unranked factors are converted to pseudo variables. For example, District is replaced with variables District $_{1}=$ Centras, District $_{2}=$ Senamiestis and so on . Each new pseudo variable can have a value of 0 or 1. Presence of the balcony is a logical factor but is evaluated as 0 or 1 . All other numerical factors are entered to the model as they are.
The next step is to improve the model by repeatedly removing and adding the variables to the model and checking the amount of dispersion it explains.

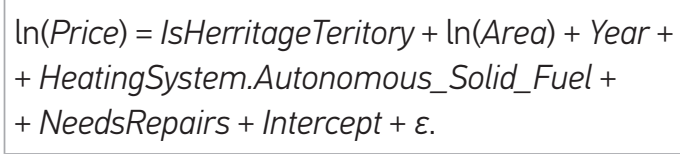

+ NeedsRepairs + Intercept $+\varepsilon$.

The model was improved by using the stepwise AIC approach and by considering correlations between separate factors, i.e., possible multicollinearity. Additionally we have used Klein's test for multicollinearity. Note that we show only IsHerritageTeritory and not coefficient - IsHerritageTeritory for simplicity. Adjusted R-squared is equal to 0.755 and the model explains about $76 \%$ of variance in the dataset. The heating system is more influential in this model although the corresponding coefficient is not statistically important due to the small sample size.

\section{Table 3}

The coefficients for factors in the hedonic regression model described by Equation 2. Second and third columns show the regression coefficients and significance levels. Note that some factors are not statistically significant $(p>0.01)$, but were preserved by stepwise regression. Significant variables are marked in bold

\begin{tabular}{l|c|c|c|c}
\hline \multirow{2}{*}{ Factor } & \multicolumn{2}{|c|}{ Coefficients } & VIF & $\begin{array}{c}\text { Klein's test } \\
\text { for multicollinearity }\end{array}$ \\
\cline { 2 - 5 } & Estimate & $\mathrm{p}$ & 4 & 5 \\
\hline (Intercept) & 2 & 3 & - & - \\
\hline IsHerritageTerritory & -2.3176 & 0.100 & 1.23 & No \\
\hline In(Area) & 0.6764 & $<2 \mathrm{e}-16$ & 1.08 & No \\
\hline Year & 0.9377 & $<2 \mathrm{e}-16$ & 1.16 & No \\
\hline HeatingSystem.Autonomous_Solid_fuel & 0.0048 & $2.39 \mathrm{e}-10$ & 1.01 & No \\
\hline NeedsRepairs & 0.3118 & 0.318 & 1.02 & No \\
\hline
\end{tabular}

Data on new construction. The correlation matrix of factor pairs of the data on new construction is presented in Fig. 2. It can be noticed that the strongest linear relationship exists between Area and Rooms (0.74). This suggests that only one of these variables could be considered in the final model. The strongest negative linear relation exists between UniqueArchitecture and Parking. This is a flag for multicollinearity. It can also be noted that Price correlates a bit more weakly to almost each factor compared with PriceSqM, but it has more statistically important ties and that again enables us to pick Price for hedonic regression and leave PriceSqM out.
At first, we enter all the factors to hedonic regression to get a broader picture of possible interconnection between the factors and the price. The model was improved by using the stepwise AIC approach again. Note that after a trivial case of considering all the factors, we construct the model for price prediction, which does not have spatial information in it, i.e., Project names, Streets and Districts are removed (Equation 3). Smaller models that have similar coefficients of determinations are often considered as optimal ones. After considering the multicollinearity and statistical importance of the hedonic regression model, the updated version is described by the formula: 
$\ln ($ Price $)=1$ s HerritageTeritory $+\ln ($ Area $)+$ + Completeness + Intercept $+\varepsilon$.

Fig. 2

Correlation matrix (Spearman rank correlation) for factor pairs of the data on new construction. The white cells depict statistically insignificant correlations $(p=0.01)$.

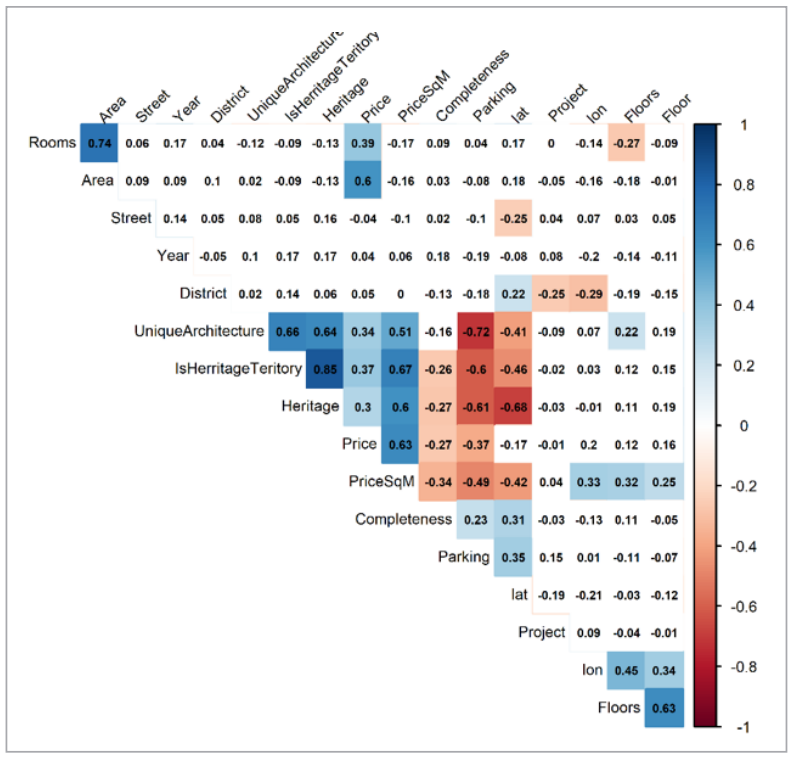

Adjusted R-squared is equal to 0.687 and the model explains about $69 \%$ of variance in the dataset. Table 4 shows that now the model is comprised of all statistically significant coefficients.

\section{Table 4}

The factors in the hedonic regression model described by Equation $3 \mathrm{~b}$. Second and third columns show the regression coefficients and significance levels. Significant variables (all) are marked in bold

\begin{tabular}{|c|c|c|c|c|}
\hline \multirow[b]{2}{*}{ Factor } & \multicolumn{2}{|c|}{ Coefficients } & \multirow[b]{2}{*}{ VIF } & \multirow{2}{*}{$\begin{array}{l}\text { Klein's } \\
\text { test for } \\
\text { multicol- } \\
\text { linearity }\end{array}$} \\
\hline & Estimate & $\mathrm{p}$ & & \\
\hline 1 & 2 & 3 & 4 & 5 \\
\hline (Intercept) & 7.7730 & $<0.000001$ & - & - \\
\hline IsHerritageTeritory & 0.4387 & $<0.000001$ & 1.09 & No \\
\hline $\ln ($ Area $)$ & 0.8965 & $<0.000001$ & 1.01 & No \\
\hline Completeness & -0.0972 & 0.00407 & 1.09 & No \\
\hline
\end{tabular}

\section{Results and Discussion}

General set of data. The research revealed the minor influence of the built heritage on the real estate pricing in Kaunas. The cultural heritage objects (the objects officially included into the Register of Cultural Heritage Properties) constitute only a few cases from the analysed sets of the data, and the influence of the cultural heritage variable is of minor significance (Fig. 1); thus, it can be concluded that the market of architectural heritage in Kaunas is not existent and only a fragmentary supply exits. Such a situation might be caused by considerable investments required by old buildings, determined by their bad physical state, from one point of view, and by the heritage preservation regulations applied for the listed buildings, which sometimes are unreasonably high. Moreover, it can be stated that the research revealed the consumptive attitude towards architectural heritage as reflected in the real estate development and pricing trends in Kaunas, i.e., businesses and buyers are not interested in investing in authentic historic built environment and choose the "neighborhood of historic buildings" instead of that. As far back as 1976, Erich Fromm, speaking about the problem of consumer society, was skeptical, although visionary, depicting the potential future of a free market for the countries of the Warsaw Pact, when a society not having particular things yet, would begin to worship them soon after acquiring, forgetting their true nature (Fromm, 1990). Based on this attitude and the research findings that the heritage aspect has no significant influence on the real estate price, the further step was the expert valuation of the districts of Kaunas regarding their links with heritage and the influence of heritage on them, in order to determine the distribution of prices of the real estate units in different districts of the city. The districts Centras and Senamiestis were considered heritage territories, the genotypes of development of the districts Žaliakalnis and Freda were determined by the heritage objects, and the substantial part of their territories is considered as heritage territory as well. Žemieji Šančiai, Aleksotas and Vilijampole are the historic suburbs, the historical structure of which was modified in the course of time; thus, heritage influence in these districts is less significant. The districts 
Eiguliai, Kalniečiai, Petrašiūnai and Aukštieji Šančiai were developed in the Soviet era and mainly built up with multistory residential buildings, where after the restoration of independence in 1990, the significant clusters of contemporary architecture have emerged replacing the industrial objects with services. The urban structure of these districts is free plan; thus, there is no heritage objects or the influence of historical architecture.

The data from Fig. 3 show that the median price and the most expensive cases of the real estate units coincide with areas where the development could be defined as urban heritage in general, and their entire territory or significant part is the officially protected area. Thus, the most expensive real estate units are located

\section{Fig. 3}

A boxplot of housing prices in various districts of Kaunas in the general set of the data. Districts where the entire territory or a significant part is an officially protected area (urban heritage) include Aleksotas, Senamiestis, Centras, Freda, Žaliakalnis and Žemieji Šančiai

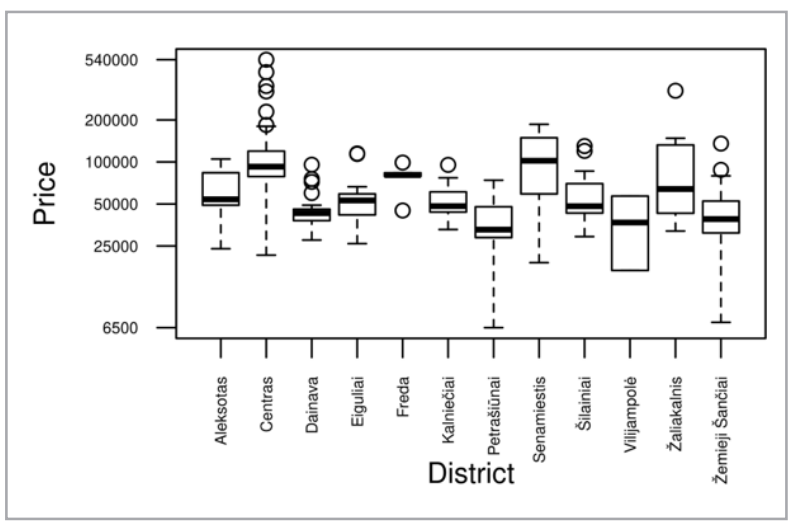

in Senamiestis, Centras, Freda and Žaliakalnis. The Aleksotas district, where the major heritage quality reveals itself as the presence of the panoramic view of the historic center, is mediating in terms of the median of the real estate prices between the so-called heritage districts and the districts that have nothing to do with heritage, i.e., the Soviet districts. On the other hand, it can be seen that the lowest real estate prices were identified not in the districts of the Soviet era, such as Šilainiai, Kalniečiai and Eiguliai, but in the historic suburbs Petrašiūnai, Žemieji Šančiai, and
Vilijampole. These districts are historical, they contain heritage values, although they are fragmented and their integrity is undermined if compared with the historic areas where the price is highest. It is necessary to note that these districts are former industrial zones where the conversion processes are now ongoing. Meanwhile, Žaliakalnis, Freda, Centras and Senamiestis are the areas of residential, administrative or mixed use, where the functional purposes are the result of historical development.

This part of the analysis demonstrates that not only the heritage value of the neighborhood is appreciated, but also the existing or, more exactly, remaining integrity of heritage objects is important. The historical urban genotype of Centras, Senamiestis, Freda or Žaliakalnis areas has historically evolved through several epochs; therefore, even later architectural and urban development of the Soviet period, even though it did not add objects of heritage or significant architectural quality, blended into historical environment without reshaping it radically (Petrulis et al., 2013). This is also explained by the fact that the new part of Žaliakalnis north of Savanoriu street, where the built fabric has mostly been formed in the Soviet times retaining the historical street network, is attractive from the real estate point of view; a similar situation was identified in Freda district.

The tendency of such pricing, where the fact that the building is historical does not create economic and financial value (Fig. 4), and this value is generated by the integrated context of historical architecture, where the historical function is either mixed or residential, or administrative, leads to the risks related to ensuring the sustainable continuity of the historic urban tissue. In the case of Kaunas, we deal with an exploitative attitude rather than an investment perspective towards the objects of cultural heritage.

The result of the search for the most important aspects influencing the real estate unit's price is that the location of the building constitutes $21 \%$ of the unit price, and $4.42 \%$ is determined by the heritage status of the area. These numbers were obtained as products of coefficients from the corresponding hedonic price model and typical values of particular factors/ aspects - medians. As previously mentioned, the 
cultural heritage status or heritage characteristics of the building itself does not cause any significant difference in the price of the real estate unit.

Mason (2002), analysing the links between the economic benefits and cultural value, emphasised the fact that increasing the economic benefits using cultural value is not a complex phenomenon. However, according to the researcher, under conditions where culture is exploited, the threshold when the cultural value starts declining is reached very quickly, consequently eliminating the preconditions for obtaining the economic benefits.

\section{Fig. 4}

Distribution of properties as price (EUR) vs year in respect of the heritage preservation zone in the general set of data

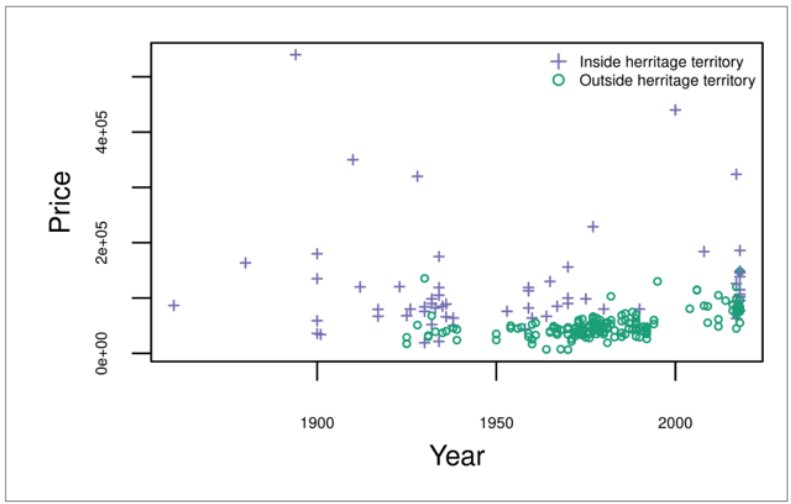

On the other hand, as shown in Fig. 4, the objects having features of cultural heritage (all objects built before 1950) constitute the cases of the highest price if compared with the objects of new construction. These are the exceptional cases, although it is clear that objects with cultural heritage features in the heritage areas constitute the most expensive real estate cases if viewed individually.

The first part of the study revealed that architectural objects from the point of view of the real estate market are not valued for their historical, cultural, artistic or other significance. The hedonic analysis reveals predominant utilitarian price components, such as the heating system ( $7 \%$ of the total value of the price, which is obtained as described above), and the year of construction (66.3\%). The important components are the district where the building is located (2\%) and the heritage status of the territory (4.4\%). However, it can be stated that the neighborhood of heritage objects may be viewed more from the utilitarian perspective, because it coincides with a better geographical location in the city as well. Taking into account that the heritage status of the building has no significant influence on the price, while the location district and heritage status of the area have the impact, it makes sense to look further into the market for newly constructed residential buildings and the influence of the heritage area on their prices.

Data on new construction. The last model showed that if spatial variables are not considered, the area is the most important factor in price. Nearby heritage objects also drop in significance in that case if compared with the initial model when all the factors were entered. The decision of eliminating the spatial information from the model was done in order to avoid overfitting due to the small dataset.

In the framework of the study, all the residential buildings built in Kaunas since 2013 inclusively are considered as new construction. This part of the research was intended to see the influence of the heritage status of the location territory and the architectural quality of the building on the price of the real estate unit. The problems related with new construction, especially in the context of historic environment, can be seen at several levels. First, as it was already mentioned, the exploitation of the cultural value of the existing historical fabric by constructing a lot of new architecture in the heritage area can be extremely harmful, because the very cultural value, which potentially generates the significant part of the economic value for new construction, is likely to be diminished. The second opposite aspect relates to the nature of urbanisation itself. Numerous heritage theorists (Vaccaro, 1996) agree that many architectural heritage properties that reached our times would not exist, if the new structures had not replaced the older ones. Based on the case studies, Fibiger (2015) suggests perceiving the loss of a material heritage as a catalyst for achieving intangible capital. The third approach relates to the aim of the harmony between the new and the old, realising that the rational quantity of new architecture in historic urban environment can enrich the historical fabric (Vienna Memorandum, 2005). 
Fig. 5 shows that the highest prices for the real estate unit of new construction were of those located in the heritage territory. This confirms the hypothesis that historic built environment automatically generates economic benefits. The analysis demonstrated that the influence of the location on the price of a real estate unit of new construction is almost $90 \%$.

\section{Fig. 5}

Price (EUR) vs year in respect of heritage territory of data on new construction

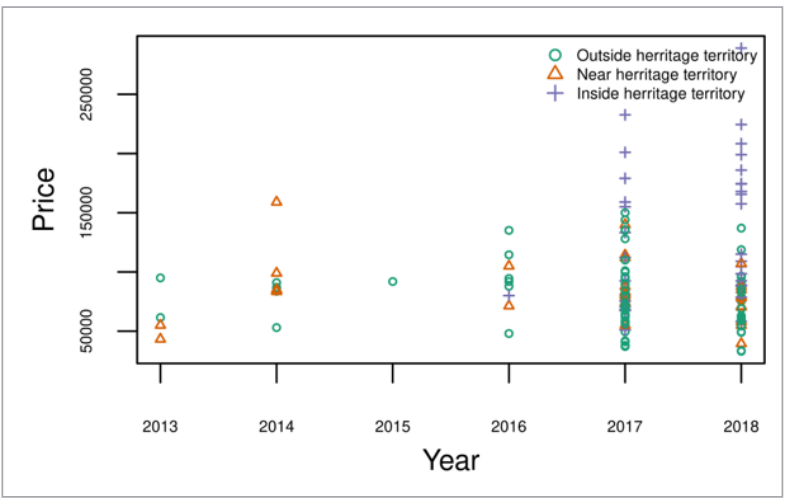

The difference in the median price (Fig. 6), when comparing the objects located in the zone of active influence of the heritage territory with the objects that have no connection with heritage, is not significant. This demonstrates that the active influence of heritage is not appreciated and the projects of lower architectural quality are developed there, even though the direct links with the heritage territory allow using the majority of non-market values used by those living in the heritage territory. Thus, it can be seen as the aspect of exploitative nature of use of heritage as a resource, threatening the sustainable development and the continuity of the city center.

This statement is also reflected in the Unique Architecture index (Figure 7). Of 29 analysed objects, 19 objects that were located in the zone of influence of heritage territories were characterised as objects of indifferent architecture; this means that from the expert point of view these buildings are not and probably will not be seen as architecturally significant, because their aesthetic solutions and materials are close to uniform repetitive designs. On the other hand, the
Fig. 6

A boxplot of housing prices (EUR) of the data on new construction. Variable IsHeritageTerritory shows whether the property is outside heritage territory $(0)$, close to it (0.5) or inside it (1)

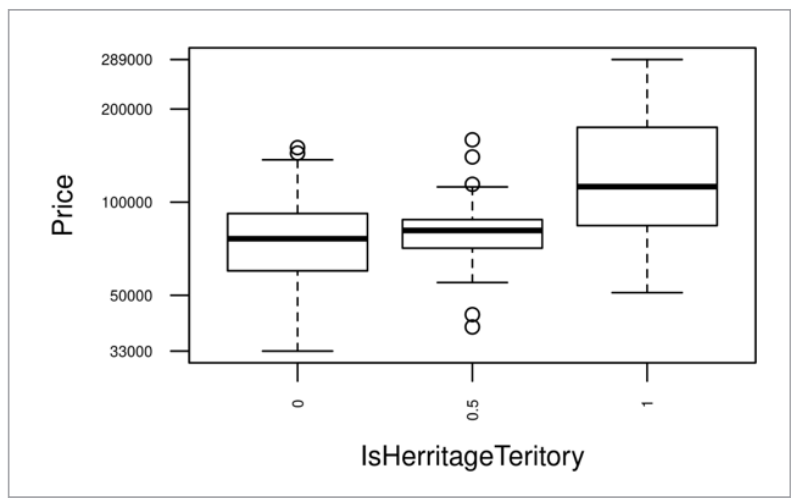

new construction objects located in the protected heritage territories, in 30 cases of 34 analysed real estate units, had some visible artistic ideas in the architecture of the building. Here it should be noted that the quality of the idea itself and the potential to become a cultural heritage object in the future are not evaluated; only the attempt to develop artistic quality is considered.

\section{Fig. 7}

The contingency table for housing items in respect of expert evaluation of uniqueness of architecture and being in the heritage territory

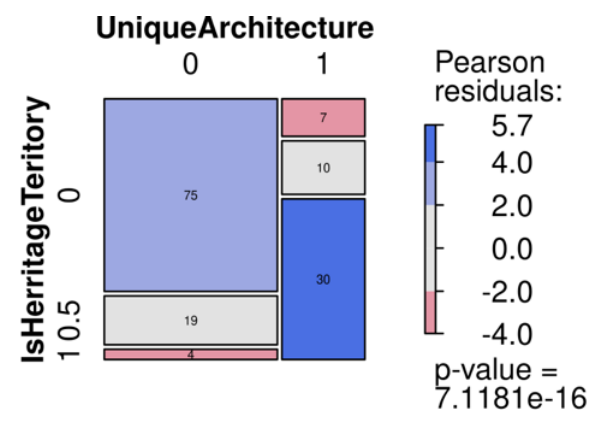

Only 4 of 98 analysed objects in non-heritage territory were located in the objects with a characteristic architectural idea; meanwhile, the absolute majority of all cases - 75 analysed objects - where located in the buildings of indifferent architecture. The comparison 
of median prices of the real estate units in the objects of indifferent architecture and of architecture having an artistic character demonstrates that the residents are willing to pay more for original architecture; however, this factor is closely linked with the location aspect as well.

\section{Fig. 8}

A boxplot of housing prices (EUR) of the data on new construction. Variable UniqueArchitecture shows whether an item possesses unique architectural features (1) or not (0)

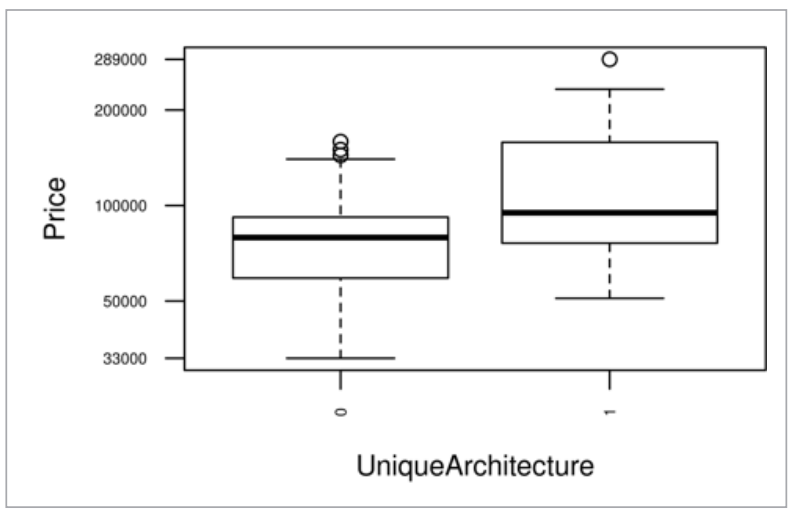

The second part of the analysis confirms the issue raised in the first part that the market of built heritage residential objects is currently non-existent in Kaunas. The analysis confirms that the projects of new residential development in existing heritage objects (reconstructions) are not typical unique cases and do not influence the median. However, it is evident that the price of renovated heritage object is usually higher; thus, it can be predicted that together with the economic growth, development of smart industries and service centres, the housing market in the heritage buildings will grow as well. On the other hand, the popularity of new construction in the heritage territories and the preferences regarding the willingness to pay of potential buyers towards these buildings if compared with authentic historic buildings can be explained with wider sociocultural trends. According to Putinaite (2007), the Soviet occupation had strongly stimulated the urge towards consumption, as the goods accessible in the West were constantly lacking here. Thus, after regaining the independence and the introduction of market economy, the willingness to acquire "contemporary" artefacts became predominant together with demonstrative careless consumption.

Currently, the heritage influence in the housing market in Kaunas is more indirect when the proximity of heritage objects is exploited by investing into non-heritage objects and new construction in heritage territories or in their zone of influence. Consequently, the objects of new construction existing in the protected heritage territories can be characterised with pretention towards higher architectural quality.

\section{Conclusions}

The analysis of Kaunas case demonstrated that the fact that the building is valuable historic property has no significant influence on its price in the housing market and the hedonic analysis suggests that buyers are not willing to pay more for this property. This can be explained by the strict operating heritage protection mechanisms, raising the investments needed for such objects, which usually are of an unsatisfactory physical state. On the other hand, the study revealed the trend to exploit the historic environment, benefiting from the proximity of heritage objects.

It was determined that the influence of the location in the heritage territory on the price of the real estate unit is $4.42 \%$, which is not high. Although in the context of the predominance of other utilitarian variables, it can be seen as in the state of transition with the prospect of growth together with rising post-materialist views in the country's socioeconomic climate.

One of the most important variables considering the preferences towards the real estate units in the housing market despite the year of construction is their location or district; it amounts to $21 \%$ of the price of the real estate unit. This variable can be seen as more utilitarian, of geographical character in the analysis; however, the districts with the highest real estate prices, including Centras, Senamiestis, Žaliakanis, and Freda, are developed under the influence of a historical urban and architectural genotype. This explains the lower prices in the other historic districts having heritage objects, although with predominant visual identity mass developed during the Soviet era. 
Considering this, the further research aimed at the assessment of indirect economic benefits of the built heritage should be targeted not only at the object itself, but also at the historical genotype.

The analysis of the situation of real estate units in new objects built starting from 2013 demonstrates that the historic built environment stimulates the emergence of higher architectural quality. The willingness to pay for such architecture is higher. However, the analysis of the zones of influence of heritage territories (the territories under visual, cultural, economic, etc. influence of heritage territories) demonstrates that the majority of analysed new objects have no distinctive architectural quality. This raises threats for the sustainable development of the central part of Kaunas, as the city centre of Kaunas has a pervasive character, oriented towards the expansion of functions into new districts.

It should be noted as well that currently the exploitative attitude is predominant in the real estate market in Kaunas; this raises the threat towards the preservation of the identity of historical environment. Heritage is a limited resource and it can be depleted if overwhelmed with new artefacts. This threat is related not only to the possible loss of valuable cultural

\section{References}

Ahlfeldt, G. M., \& Maennig, W. (2012). Substitutability and complementarity of urban amenities: external effects of built heritage in Berlin. Real Estate Economics, 38(2), 285-323. https:// doi.org/10.1111/j.1540-6229.2010.00268.x

Anderson, S. T., \& West, S. E. (2006). Open space, residential property values, and spatial context. Regional Science and Urban Economics, 36, 773 - 789. https://doi.org/10.1016/j.regsciurbeco.2006.03.007

Bilbao-Terol, C., Cañal-Fernández, V., Valdés, L., Del Valle, E. (2017). Rural tourism accommodation prices by land use-based hedonic approach: First results from the case study of the self-catering cottages in Asturias. Sustainability, 10(9), 1688. https://doi.org/10.3390/su9101688

Burinskienè M., \& Rudzkienè V. (2006). Želdynų įtaka gyvenimo kokybei ir būsto kainai Vilniuje. Urbanistika ir architektūra, 30 , $30-37$.

Donnelly W. A. (1999). A survey in applied environometrics: the hedonic valuing of environmental amenities. Environment properties in the case when the objects of new construction become predominant in the central part of the city, but also to the decline of economic benefits, prices and attractiveness of the area.

Moreover, looking at individual real estate cases, it can be seen that the most expensive objects are in the historic buildings located in the heritage territories. As the large part of such objects now are of non-satisfactory physical state, the significant real estate market potential can be predicted here. Such potential is related to post-materialist attitudes and their emergence in public and private lives, the growing foreign investment in Kaunas and its zone of influence and the economic growth in Lithuania and increasing salaries.

\section{Acknowledgements}

This research was carried out in the frame of the project "Conceptual Methodology for Heritage Value Reification to Social Economic Benefits" under the programme of research group development at Kaunas University of Technology in priority scientific fields. This work was supported by Kaunas University of Technology under Grant APSENIM [PP32/1815].

International, 17, 547 - 558. https://doi.org/10.1016/01604120(91)90167-0

Fan G. Z., Ong S. E., Koh C. H. (2006). Determinants of house price: a decision tree approach. Urban Studies, 43, 2301 - 2315. https://doi.org/10.1080/00420980600990928

Fibiger Th. (2015). Heritage erasure and heritage transformation: how heritage is created by destruction in Bahrain. Intyernational Journal of Heritage Studies, 21(4). 390-404. https:// doi.org/10.1080/13527258.2014.930064

Franco S. F., Macdonald J. L. (2018). The effects of cultural heritage on residential property values: evidence from Lisbon, Portugal. Regional Science and Urban Economics, 70, 35-56. https://doi.org/10.1016/j.regsciurbeco.2018.02.001

Fromm E. (1990). Turèti ar būti? Vilnius. Vaga.

Gabrielli, L., Farinelli, V. (2017) Valuing the historical heritage: the case of the Venetian Villas in Italy. Journal of Cultural Heritage Management and Sustainable Development, 7(4), 407429. https://doi.org/10.1108/JCHMSD-09-2016-0054 
Girard L. F., Baycan T., Nijkamp P. (2012) Sustainable city and creativity - promoting creative urban initiatives. Routledge.

Jayantha, W., \& Lau, J. (2016). Buyers' property asset purchase decisions: an empirical study on the high-end residential property market in Hong Kong. International Journal of Strategic Property Management, 20(1), 1-16. https://doi.org/10.3846/1 648715X.2015.1105322

Jim C. Y., \& Chen W. Y. (2006) Impacts of urban environmental elements on residential housing prices in Guangzhou (China). Landscape and Urban Planning, 78, 422 - 434. https://doi. org/10.1016/j.landurbplan.2005.12.003

Lazzaro, E. (2006). Assesing quality in cultural goods: the hedonic value of originality in Rembrandt's prints. Journal of Cultural Economics, 30, 15 - 40. https://doi.org/10.1007/s10824-005-1918-0

Lazrak F., Nijkamp P., Rietveld P., Rouwendal J. (2014). The market value of cultural heritage in urban areas: an application of spatial hedonic pricing. Journal of Geographical Systems, 16(1), 89-114. https://doi.org/10.1007/s10109-013-0188-1

Lazrak F., Nijkamp P., Rietveld P., Rouwendal J. (2009). Cultural heritage: hedonic prices for non-market values. Serie Research Memoranda 0049, VU University Amsterdam, Faculty of Economics, Business Administration and Econometrics.

Mason R. (2002) Assesing values in conservation planning: methodological issues and choices. In: De la Torre M. Assessing the values of cultural heritage. Getty Conservation Institute, Los Angeles, 5 - 30.

Mason R. (2005). Economics and historic preservation: a guide and review of the literature. Discussion paper prepared for the Brookings Institution Metropolitan Policy Program. Washington.

Monson, M. (2009). Valuation using hedonic pricing models. Cornell Real Estate Review, 7, 62-73.

Moro, M., Mayor, K., Lyons, S., Tol, R. S. J. (2013). Does the housing market reflect cultural heritage? A case study of Greater Dublin. Environment and Planning A, 45, 2884-2903. https:// doi.org/10.1068/a45524

Mourato, S., Mazzanti, M. (2002). Economic valuation of cultural heritage: evidence and prospects. In: De la Torre M. Assessing the values of cultural heritage. Los Angeles: Getty Conservation Institute, 51 - 76.

Navrud, S., Ready, R. C. (2002). Valuing cultural heritage. Applying environmental valuation techniques to historic buildings, monuments and artefacts. Edward Elgar Northampton. https://doi.org/10.4337/9781843765455

Nilsson, P. (2011). Cultural landscape characteristics and heritage values. A spatially explicit hedonic approach. ERSA conference papers ersa10p397, European Regional Science Association.

Oba, T., \& Noonan, D.S. (2017). The many dimensions of historic preservation value: national and local designation, internal and external policy effects. Journal of Property Research, 34(3), 211-232. https://doi.org/10.1080/09599916.2017.1362027

Putinaitè N. (2007). Nenutrūkusi styga. Prisitaikymas ir pasipriešinimas Sovietų Lietuvoje. Vilnius. Aidai.

Petrulis V. et al. (2013). Lietuvos tarpukario architektūros palikimas: materialumo ir nematerialumo dermè. Kaunas. KTU.

Ruijgrok, E. C. M. (2006). The three economic values of cultural heritage: a case study in the Netherlands. Journal of Cultural Heritage, 7, 206 - 213. https://doi.org/10.1016/j.culher.2006.07.002

Ryan, B. D. \& Weber, R. Valuing new development in distressed urban neighborhoods - does design matter? Journal of American Planning Association, 73, 100 - 111. https://doi. org/10.1080/01944360708976139

Saló, A., Garriga, A., Rigall-I-Torrent, R., Vila, M., Fluvià, M. (2014). Do implicit prices for hotels and second homes show differences in tourists' valuation for public attributes for each type of accommodation facility? International Journal of Hospitality Management, 36, 120-129. https://doi.org/10.1016/j. ijhm.2013.08.011

Steiner, A., McCormic, S. J., Johnson, J. (2004). How much is an ecosystem worth? Assessing the economic value of conservation. The International Bank for Reconstruction and Development, The World Bank, Washington.

Throsby, D. (2002). Economics and culture. Cambridge: Cambridge University Press.

Tita, G. E., Petras, T. L., Greenbaum, R. T. (2006). Crime and residential choice: a neighborhood level analysis of the impact of crime on housing prices. Journal of Quantitative Criminology, 22, 299 - 317. https://doi.org/10.1007/s10940-006-9013-z

UNESCO. World heritage Center. (2005). Vienna Memorandum on World Heritage and Contemporary Architecture - Managing the Historic Urban Landscape.

Vaccaro M., Price N. S., \& Talley jr. M. (1996). Historical and Philosophical issues in the Conservation of Cultural Heritage. Readings in Conservation Series. Los Angeles. The Getty Publications.

Xiao Y. (2017). Urban morphology and housing market. Springer, 11-40. https://doi.org/10.1007/978-981-10-2762-8

Wen, H., Jin, Y., \& Zhang, L. (2017). Spatial heterogeneity in implicit housing prices: evidence from Hangzhou, China. International Journal of Strategic Property Management, 21(1), 15-28. https://doi.org/10.3846/1648715X.2016.1247021 